\title{
Post-exercise effects of graduated compression garment use on skeletal muscle recovery and delayed onset muscle soreness: a systematic review
}

\author{
Aline Machado Araujo ${ }^{1}$, Rodrigo Kohn Cardoso $^{1}$, Airton José Rombaldi ${ }^{1}$
}

REVIEW ARTICLE

\begin{abstract}
The study aimed to review the literature on the effects related to post-exercise of graduated compression garments (GCGs) use on muscle recovery and delayed onset muscle soreness. The search was performed in Pubmed/Medline, Bireme, Scielo, and Lilacs electronic databases using the following descriptors in English: "compression clothing", "physical exercise", "recovery", "physical activity", "compression stockings" and "delayed onset muscle soreness". The search resulted in 102 articles and after removing duplicates, applying exclusion criteria and checking the reference lists, nine studies fulfilled the criteria and were included in the review. Seven studies associated the use of GCGs with reduction of delayed muscle soreness and improvement in performance after the use of compression clothes. However, the methodological quality of the studies, using PEDro scale, presented an average of $5.1 \pm 0.9$ points (out of a total of 11 points), classified as intermediate. In conclusion, although the positive effects of using CGCs on improving recovery and reduction of delayed muscle soreness after physical exercises are almost consensual, the insufficient methodological quality of the included studies requires careful consideration of the results. Keywords: Muscle damage, compression garment, venous return, exercise, muscle soreness, recovery.
\end{abstract}

\section{INTRODUCTION}

The use of graduated compression garments (GCGs) has shown to be efficient in the prevention and treatment of lymphatic and venous diseases (Kelechi, Johnson \& WOCN Society, 2012; Nelson \& Bell-Syer, 2012), pathologies which affect the population in general due to prolonged standing or sitting positions (Fernandes, Rodrigues \& Vianna, 2011; França \& Tavares, 2003). The use of these compression accessories aims to reduce inflammatory mediators, promote drainage of metabolites, increase venous return and decrease edema (swelling), favoring the transport of oxygen to the skin and subcutaneous tissue in order to accelerate the healing of venous ulcers (Partsch, Flour \& Smith, 2008; Figueiredo, Filho \& Cabral, 2004). The advantages derived from the use of GCGs have created a demand for the industry to improve the quality and increase the quantity of GCGs (Gill, Beaven \& Cook, 2006) in order to meet the demands ranging from medical to sports fields (Simao, Farinatti, Polito, Maior \& Fleck, 2007; Ali, Caine \& Snow, 2007).

In sports, the GCGs are used aiming at a number of benefits, including attenuating physical stress, improving performance, delaying fatigue and providing faster recovery after muscle stress (Bringard, Perrey \& Belluye, 2006). The first experiment using GCG in the sports environment was carried out in 1987. The study aimed to verify the acute effects of compression socks during a physical exercise session on performance markers and found that when subjects used the socks, they showed lower concentrations of blood lactate, suggesting faster muscle recovery (Berry \& McMurray, 1987). The authors hypothesized that the positive action was because the compression socks strengthen the action of the muscular pump on the back of the legs increasing the return of the venous blood to the heart, producing indirect benefits on the levels of lactate post-activity and reduction of

\footnotetext{
Manuscript received at January $17^{\text {th }} 2018$; Accepted at June $27^{\text {th }} 2018$

${ }^{1}$ Physical Education Postgraduate Program, Federal University of Pelotas, Pelotas, Brazil

*E-mail: lynema21@yahoo.com.br
} 
trauma (Kraemer et al., 1998; Kraemer et al., 2001).

In order to achieve better results and to reduce muscle damage caused by strenuous physical exercise, previous studies have explored the use of GCGs in reducing physical exhaustion and delayed pain (Kemmler et al., 2009; Bringard et al., 2006; Driller \& Halson, 2013). In this sense, GCGs use showed efficiency in mitigating the impact of physical exercise on muscle fibers, preventing cell loss and favoring post-exercise recovery (Doan et al., 2003). The explanation for this process states that, as a consequence of physical exercise, the sarcolemma is damaged leading to a reduction of calcium homeostasis, a process accompanied by cellular necrosis. The presence of cellular waste and immune cells, in turn, leads to inflammation, which is characterized by edema and muscle pain. The use of GCGs aims to reduce the occurrence of injuries (Ali et al., 2007; Berry \& McMurray, 1987).

Considering that the use of GCGs has been related to numerous benefits (Chatard et al., 2004; Ali, Creasy \& Edge, 2010) after strenuous physical exercises (either by intensity or duration or both), this systematic review aimed to summarize studies about the effects of the postexercise GCGs use on muscle recovery and delayed onset muscle soreness.

\section{METHOD}

\section{Search Strategy}

In the present systematic review, experimental studies aimed to measure the effects of the post-exercise use of GCGs on muscle recovery and delayed onset muscle soreness were selected. An electronic search was performed in PUBMED / MEDLINE, BIREME, SCIELO, LILACS databases, selecting articles published from January 2005 to March 2017.

The selection of the descriptors used throughout the review process was done according to the Medical Subject Headings $(\mathrm{MeSH})$. The following descriptors were used in English: "compression garments", "exercise", "physical activity", "recovery", "delayed onset muscle soreness" and "compression stockings". In order to combine the descriptors and terms used in the search, we used the logical operators "and" and "or".

\section{Eligibility criteria and selection of studies}

The studies included in this review were randomized controlled trials (RCTs), which presented the "muscle recovery" or "late pain" or "delayed onset muscle soreness" variables, written in English and published since 2005. Articles with deficiencies in the methodological description, especially with regard to objectives, methods, results and conclusions were excluded from the search.

Based on the Preferred Reporting Items for Systematic Reviews and Meta-Analysis (PRISMA; Liberati et al., 2009) diagram, two authors independently assessed all included studies. In case of disagreement between the reviewers regarding the evaluation of the studies, an attempt was made to resolve by consensus, and when this was not possible a third reviewer was consulted. PEDro scale (Shiwa et al., 2011) was used to determine the methodological quality of the studies, that is, to identify clinical studies with appropriate internal validity and sufficient statistical information to make the results interpretable. PEDro scale consists of 11 items, each item contributing one point, and the total score varies from 0 (zero) to 10 (ten) points (the first item is not considered in the final score). The selection of the studies was carried out first by the title; after by the reading of the abstracts, and finally by the complete reading of the article.

\section{RESULTS}

The search resulted in 102 articles, from which 73 were excluded because they were not experimental studies. After reading the abstracts, 12 studies were excluded because they did not use post-exercise GCGs and eight for other reasons, such as using GCGs during exercise. In total, nine articles met the eligibility criteria and were included in the review (Figure 1). 


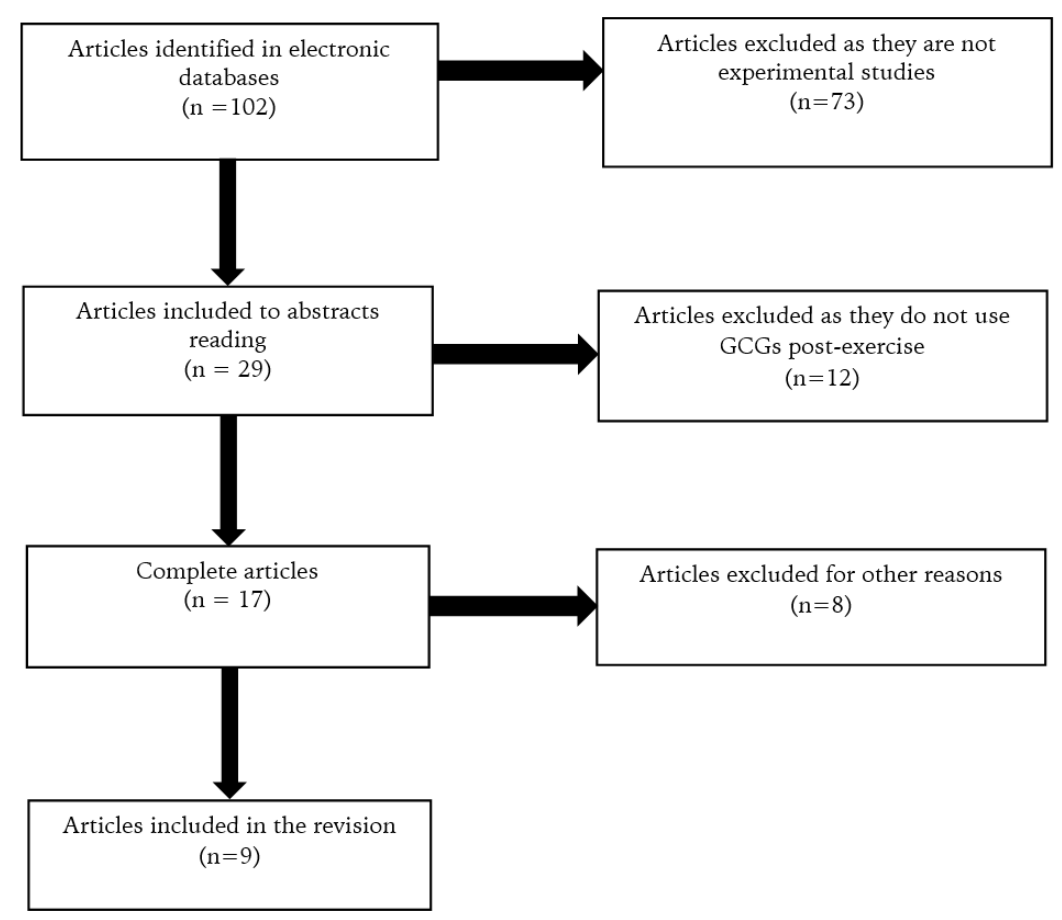

Figure 1. Flowchart for selection of systematic review articles.

The articles included in this review used GCGs in a period between 12 and 72 hours post intervention. The study samples were composed of physically active individuals or athletes, most of them exclusively male (Chan, Duffield \& Watsford, 2016; De Glanville \& Hamlin, 2012; Hamlin et al., 2012; Sperlich, Born, Kaskinoro, Kalliokoski \& Laaksonen, 2013); two studies used only women (Jakeman, Byrne \& Eston, 2010; Jakeman, Byrne \& Eston, 2010 b), and three used groups from both sexes (Hill, Howatson, Van Someren, Walshe \& Pedlar, 2014, Hill et al., 2017; Kraemer et al., 2010).

The subjects of the articles included in this review used post-intervention GCGs for a period of time ranging from 12 to 72 hours (mean of 33 \pm 24.6 hours) (Jakeman, Byrne \& Eston, 2010; Jakeman, Byrne \& Eston, 2010b). Hill, Howatson, Van Someren, Walshe \& Pedlar, 2014, Hill et al., 2017). Regarding the GCGs used in the interventions, six studies used compression pants (De Glanville \& Hamlin, 2012, Hammann et al., 2012, Jakeman, Byrne \& Eston, Van Someren, Walshe \& Pedlar, 2014; Hill et al., 2017), one study reported using full body clothing (Kraemer et al., 2010), one study used compression shorts and sleeves (Chan et al., 2016) and in one study, subjects used compression shorts (Sperlich et al., 2013).
The age of the participants ranged from 20 to 25 years in six studies (Chan et al., 2010, Jakeman et al., 2010, Jakeman et al., 2010 b, Kraemer et al., 2010, Sperlich et al., 2013) and between 35 and 50 years in three reports (De Glanville \& Hamlin, 2012, Hill et al., 2014, Hill et al., 2017).

The protocols used were diverse: in two studies (Hamlin et al., 2012, Hill et al., 2014) GGCs were used soon after high-intensity running, such as sprints (Hamlin et al., 2012); in three of the studies (Hill et al., 2017; Jakeman et al., 2010b; Jakeman et al., 2010) the GCGs were used after plyometric jumps to induce muscle damage; in two (De Glanville \& Hamlin, 2012; Sperlich et al. , 2013) the effect of compression shorts after a long-distance cycling training session was analyzed; in one the effects of GCGs use were verified after a marathon (Hill et al., 2014); and one used the GCGs after a period of work included exhaustive movements such as manipulating and transporting moderately heavy to heavy loads or in uncomfortable postures such as squatting (Chan et al., 2016).

From the nine articles included in the review, seven found significant differences in muscle recovery and / or delayed onset muscle soreness after GCGs use (Chan et al., 2016; De Glanville \& Hamlin, 2012; Hamlin et al., 2012; Hill et al., 
2014; Hill et al., 2017; Kraemer et al., 2010) and two reported no statistically significant differences (Jakeman et al., 2010 b; Sperlich et al., 2013). The method used to measure delayed onset muscle soreness varied between the studies: four of them (Hamlin et al., 2012; Jakeman et al., 2010; Jakeman et al., 2010 b; Kraemer et al., 2010) used the visual analog scale (VAS) with a variation from zero (no pain) to 10 (a lot of pain); two studies (Hill et al., 2004; Hill et al., 2017) also used VAS, but the variation was between zero (no pain) and 200 (maximum pain); one study (Chan et al., 2016) measured muscle pain through a Likert scale ranging from zero (no pain) to 11 (extreme pain) and two studies (De Glanville \& Hamlin, 2012; Sperlich et al., 2013) did not report how late pain was measured.

Seven studies (Chan et al., 2016; Hamlin et al., 2012; Hill et al., 2014; Hill et al., 2017; Jakeman et al., 2010; Jakeman et al., 2010 b; Kraemer et al., 2010) have investigated the effect of GCGs on muscle damage based on the serum concentration of creatine phosphokinase (CK) and only Kraemer et al. (2010) reported a positive effect of the use of GCGs on the concentration of these enzyme. In addition, two studies analyzed the effect of GCGs on blood lactate concentration, but did not report any statistically significant difference between the groups (Duffield et al., 2008; De Glanville \& Hamlin, al., 2012). Table 1 summarizes the studies included in this review.

Regarding methodological quality, the included studies presented a mean score of 5.1 ( \pm 0.9) points, varying from 4.0 (Kraemer et al., 2010) to 7.0 points (De Glanville \& Hamlin, 2012). When the scale was divided into terciles, most studies were classified as intermediate (Chan et al., 2016; Hamlin et al., 2012, Hill et al., 2017, Jakeman et al., 2010, Jakeman et al., 2010 b) and only one study in the upper tercile (De Glanville \& Hamlin, 2012), demonstrating the regular methodological quality of the studies (table 2).

\section{DISCUSSION}

The studies included in this review aimed to investigate the effect of GCGs on similar outcomes with different exercise protocols (Chan et al., 2016; De Glanville \& Hamlin, 2012; Hamlin et al., 2012; Hill et al., 2014; Hill et al., 2017; Jakeman et al., 2010 b; Kraemer et al., 2010); most of them concluded that the use of GCGs significantly reduced delayed onset muscle soreness, generated a faster recovery and decreased fatigue caused by physical exercise.

The studies of Hill et al. (2014) and Hamlin et al. (2012) reported a reduction in post-exercise muscle pain when using GCGs. This finding can be explained by the improvement in blood circulation, allowing greater efficiency in venous blood removal, as well as reducing muscle microtrauma, promoting reduction of swelling and psychological comfort. In this sense, the benefits of GCGs use seem to be an important aid in recovery (Hamlin et al., 2012; Hill et al., 2014).

Since the rules of many competitive sports do not allow the use of GCGs during competition, research has suggested that compression clothes may be suitable as a recovery aid (Kraemer et al., 1996). In this sense, reduction in several blood variables associated with muscle injury and metabolism were reported after using GCGs as a recovery aid (Goto \& Morishima, 2014). However, studies reporting results of performance-related blood markers to support the use of garments in order to improve recovery are scarce (Kraemer et al., 1996).

Chatard et al. (2004) reported improvement in metabolic recovery (reduced lactate concentrations) during GCGs use and a better performance in the second of the two five-minute exercise bouts separated by 80 minutes of recovery. In addition, Duffield \& Portus (2007) reported a reduction in CK values 24 hours after repeated sprints, but not in performance measures 24 hours after the exercise. Therefore, compression is likely to reduce swelling and limit the acute inflammatory response leading to increased muscle damage (Kraemer et al., 2001). However, Duffiel \& Portus (2007) reported that, despite controlling exercise variables in the 24 hours post-intervention, fluid and food intake were not controlled, which may have interfered in the results. 
Table 1

Summary of the articles included.

\begin{tabular}{|c|c|c|c|c|c|}
\hline $\begin{array}{c}\text { Author } \\
\text { (year) }\end{array}$ & Sample & Objective & Design/intervention & Outcomes & Main results \\
\hline 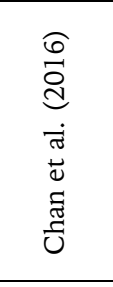 & $\begin{array}{c}10 \text { men } \\
(23 \pm 3 \text { years })\end{array}$ & $\begin{array}{l}\text { To investigate the effects of the use of } \\
\text { GCGs } 24 \text { hours after a protocol } \\
\text { simulating manual laboring tasks. }\end{array}$ & $\begin{array}{l}\text { Subjects performed, divided into two groups - with } \\
\text { or without CGGs use, circuit composed of } 10 \\
\text { stations: } 9 \text { minutes of continuous exercise followed } \\
\text { by } 3 \text { minutes of standing recovery, during } 4 \text { hours of } \\
\text { physical work, using laboring tasks to manipulate } \\
\text { and carry loads or in postures uncomfortable as } \\
\text { squatting. }\end{array}$ & $\begin{array}{l}\text { - CK; } \\
\text { - CRP; } \\
\text { - Maximal handgrip strength or } \\
\text { knee flexion torque; } \\
\text { - Maximum knee extension. }\end{array}$ & $\begin{array}{l}\text { CGCs use reduced CRP, } \\
\text { perceived muscle pain, fatigue } \\
\text { and perceived exertion during } \\
\text { subsequent workload. }\end{array}$ \\
\hline 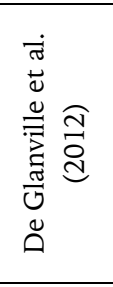 & $\begin{array}{c}14 \text { men } \\
(33.8 \pm 6.8 \text { years })\end{array}$ & $\begin{array}{l}\text { To investigate the GCGs' use } \\
\text { during a } 24 \text { hours recovery period } \\
\text { post cycling } 40 \mathrm{~km} \text {. }\end{array}$ & $\begin{array}{l}\text { RCT - the subjects used CGGs or placebo after } \\
\text { performing } 40 \mathrm{~km} \text { of cycling. After } 24 \text { hours of } \\
\text { recovery, CGCs (or placebo) was removed and the } \\
\text { second } 40 \mathrm{~km} \text { test was performed to verify the effect } \\
\text { on subsequent performance. }\end{array}$ & $\begin{array}{l}\text { - Oxygen cost; } \\
\text { - Heart rate; } \\
\text { - Blood lactate; } \\
\text { - Blood pressure; } \\
\text { - SPE; } \\
\text { - Hydration state } \\
\text { - Body weight. } \\
\end{array}$ & $\begin{array}{l}\text { There were no change in the SPE } \\
\text { index, oxygen cost, blood lactate, } \\
\text { hydration and body weight. }\end{array}$ \\
\hline 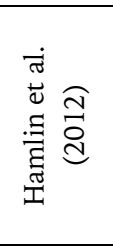 & $\begin{array}{c}22 \text { men } \\
(20.1 \pm 2.1 \text { years })\end{array}$ & $\begin{array}{l}\text { To investigate if GCGs use } \\
\text { (compression } \pm 13.4 \text { mmHg) } \\
\text { during a } 24 \text { hours period before a } \\
\text { session training, could improve } \\
\text { sprint and } 3 \mathrm{~km} \text { running } \\
\text { performance. }\end{array}$ & $\begin{array}{l}\text { RCT - the subjects used CGGs or placebo } 24 \text { hours } \\
\text { after circuit simulating a rugby match. After } 24 \\
\text { hours of recovery, sprints were performed followed } \\
\text { by } 3 \mathrm{~km} \text { of running. }\end{array}$ & $\begin{array}{l}\text { - CK; } \\
\text { - Muscle pain; } \\
\text { - Muscle fatigue; } \\
\text { - Blood lactate. }\end{array}$ & $\begin{array}{l}\text { The CGCs' use reduced fatigue } \\
\text { and muscle pain during the tests. }\end{array}$ \\
\hline 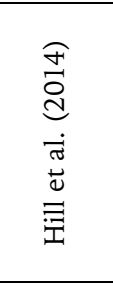 & $\begin{array}{l}24 \text { persons } \\
\text { (7 women; } 17 \\
\text { men) }\end{array}$ & $\begin{array}{l}\text { To investigate the efficacy of lower } \\
\text { limbs GCGs' use after } 72 \text { hours a } \\
\text { marathon performance (compression } \\
\text { varied between } 9.9-24.4 \mathrm{mmHg} \text { ). }\end{array}$ & $\begin{array}{l}\text { Individuals completed a marathon race and were } \\
\text { divided into } 2 \text { groups (CGCs or placebo). The } \\
\text { treatment group used CGCs for } 72 \text { hours after the } \\
\text { race. The placebo group received a single } 15 \text {-minute } \\
\text { ultrasound treatment. }\end{array}$ & $\begin{array}{l}\text { - Perceived muscle pain; } \\
\text { - Isometric maximal voluntary } \\
\text { contraction; } \\
\text { - CK; } \\
\text { - CRP. }\end{array}$ & $\begin{array}{l}\text { The perceived muscle pain and } \\
\text { SPE were significantly lower in } \\
\text { the CGCs group } 24 \text { hours after } \\
\text { the marathon race. There were no } \\
\text { significant effects for maximal } \\
\text { voluntary isometric contraction, } \\
\text { CK and CRP. }\end{array}$ \\
\hline 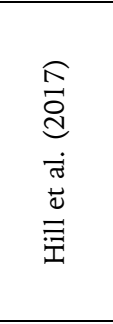 & $\begin{array}{l}45 \text { persons } \\
(26 \text { men; } 19 \\
\text { women })\end{array}$ & $\begin{array}{l}\text { To investigate different thigh and } \\
\text { calf compression rates: high } \\
\text { compression }(14.8 \pm 2.2 \mathrm{mmHg} \\
\text { on thigh and } 24.3 \pm 3.7 \mathrm{mmHg} \text { on } \\
\text { calf) versus low compression ( } 8.1 \\
\pm 1.3 \mathrm{mmHg} \text { on y } \\
\text { thigh and } 14.8 \pm 2.1 \mathrm{mmHg} \text { on } \\
\text { calf) during a } 72 \text { hours period. }\end{array}$ & $\begin{array}{l}\text { Subjects completed } 100 \text { jumps from a } 0.6 \mathrm{~m} \\
\text { platform }-5 \text { sets of } 20 \text { jumps, with } 10 \text { seconds } \\
\text { between each jump and } 1 \text {-minute rest period } \\
\text { between sets. The sample used for } 72 \text { hours after the } \\
\text { protocol different compression rates CGCs. }\end{array}$ & $\begin{array}{l}\text { - Perceived pain; } \\
\text { - Maximal voluntary contraction } \\
\text { of knee extensors; } \\
\text { - Jump height in movement; } \\
\text { - CK; } \\
\text { - CRP; } \\
\text { - Myoglobin. }\end{array}$ & $\begin{array}{l}\text { The recovery post } 72 \text { hours was } \\
\text { higher during the high } \\
\text { compression CGCs use. }\end{array}$ \\
\hline
\end{tabular}




\begin{tabular}{|c|c|c|c|c|c|}
\hline 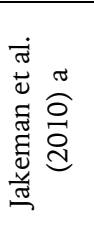 & $\begin{array}{c}17 \text { women } \\
(2.4 \pm 1.7 \text { years })\end{array}$ & $\begin{array}{l}\text { To investigate the efficacy of } \\
\text { CGCs' use (compression rate: } \\
17.3 \mathrm{mmHg} \text { on calf and } 14.9 \\
\text { mmHg on thigh) as a recovery } \\
\text { strategy during } 12 \text { hours after } \\
\text { physical exercise muscle damage. }\end{array}$ & $\begin{array}{l}\text { Individuals completed plyometric jumps to induce } \\
\text { muscle damage and were divided into } 2 \text { groups: } \\
\text { CGCs use or control groups. }\end{array}$ & $\begin{array}{l}\text { - Perceived muscle pain; } \\
\text { - CK; } \\
\text { - Concentric strength knee } \\
\text { extensors; } \\
\text { - Vertical jump performance. }\end{array}$ & $\begin{array}{l}\text { There was no significant effect on } \\
\text { CK activity. }\end{array}$ \\
\hline 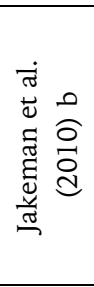 & $\begin{array}{c}32 \text { women } \\
(2.4 \pm 1.7 \text { years })\end{array}$ & $\begin{array}{l}\text { To determine the efficacy of } \\
\text { combined manual massage and } \\
\text { GCGs' use (compression: } 17.3 \mathrm{mmHg} \\
\text { on calf and } 14.9 \mathrm{mmHg} \text { on thigh) or } \\
\text { CGCs' use only during } 12 \text { hours } \\
\text { period after muscle damage. }\end{array}$ & $\begin{array}{l}\text { Individuals completed plyometric jumps to induce } \\
\text { muscle damage and were divided into } 3 \text { groups: } \\
\text { massage plus CGCs - } 30 \text { minutes of massage } \\
\text { followed by } 11.5 \text { hours of CGCs; CGCs for } 12 \text { hours; } \\
\text { and control. }\end{array}$ & $\begin{array}{l}\text { - Muscle damage index } \\
\text { (perceived pain); } \\
\text { - CK; } \\
\text { - Isokinetic muscle strength } \\
\text { "squat" jump; } \\
\text { - Countermovement jump } \\
\text { performance. }\end{array}$ & $\begin{array}{l}\text { The recovery was similar in both } \\
\text { groups. }\end{array}$ \\
\hline 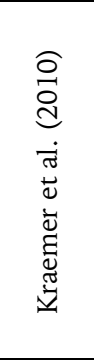 & $\begin{array}{c}20 \text { persons } \\
(23.1 \pm 2.2 \text { years })\end{array}$ & $\begin{array}{l}\text { To assess the effects of CGCs' use } \\
\text { in the whole body during a } 24 \\
\text { hours recovery period after } \\
\text { strength training. }\end{array}$ & $\begin{array}{l}\text { Individuals divided into two groups (CGCs or } \\
\text { placebo) to evaluate recovery process } 24 \text { hours after } \\
\text { a protocol of } 8 \text { strength exercises for the whole body. }\end{array}$ & $\begin{array}{l}\text { - Sleep quality; } \\
\text { - Vitality rate; } \\
\text { - Fatigue rate; } \\
\text { - Muscle pain; } \\
\text { - Muscle swelling; } \\
\text { - Reaction movement time } \\
\text { - Throwing force and vertical } \\
\text { jump; } \\
\text { - CK. }\end{array}$ & $\begin{array}{l}\text { Individuals who used CGCs had a } \\
\text { higher vitality rate, lower fatigue } \\
\text { rate, muscular pain and muscle } \\
\text { swelling, higher throwing force } \\
\text { and lower CK activity when } \\
\text { compared to the placebo group. }\end{array}$ \\
\hline 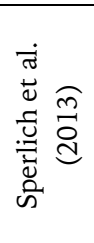 & $\begin{array}{c}6 \text { men }(22 \pm 2 \\
\text { years })\end{array}$ & $\begin{array}{l}\text { To investigate if the CGCs' use } \\
\text { (short pants that reach only to the } \\
\text { thighs - } 35 \mathrm{mmHg} \text { ) in recovery } \\
\text { after high intensity exercise, } \\
\text { improve skeletal muscle blood } \\
\text { flow and glucose uptake. }\end{array}$ & $\begin{array}{l}\text { 10-min warm-up, high intensity cycling to } \\
\text { exhaustion, 1-min of recovery followed by cycling at } \\
75 \% \text { of peak oxygen uptake and post-exercise } \\
\text { measurements. }\end{array}$ & $\begin{array}{l}\text { - Blood flow to skeletal } \\
\text { muscular; } \\
\text { - Biceps and quadriceps glucose } \\
\text { uptake. }\end{array}$ & $\begin{array}{l}\text { Compression shorts did not } \\
\text { increase muscle blood flow and } \\
\text { therefore did not lead to } \\
\text { increased supply of energy } \\
\text { substrates or increased muscle } \\
\text { glucose uptake. }\end{array}$ \\
\hline
\end{tabular}

Note: $\mathrm{CK}=$ creatine kinase; CRP = C-reactive protein; CGCs = compression graduated clothes; SPE = Subjective perception of exertion; CGS = Compression stockings; RCT = Randomized controlled trial. 
Table 2

Methodological quality of the studies included, according to PEDro scale.

\begin{tabular}{|c|c|c|c|c|c|c|c|c|c|c|c|}
\hline \multirow[b]{2}{*}{ Study (year) } & \multicolumn{11}{|c|}{ Criteria } \\
\hline & 1 & 2 & 3 & 4 & 5 & 6 & 7 & 8 & 9 & 10 & Total \\
\hline Chan et al. (2016) & + & - & + & - & - & - & + & + & + & + & 6 \\
\hline Hamlin et al. (2012) & + & - & + & - & + & - & + & + & + & - & 6 \\
\hline Hill et al. (2014) & + & - & + & - & - & - & - & + & + & - & 4 \\
\hline Hill et al. (2017) & + & - & + & - & - & - & - & + & + & + & 5 \\
\hline Jakeman et al. (2010) b & + & - & + & - & - & - & - & + & + & + & 5 \\
\hline Kraemer et al. (2010) & + & - & + & - & - & - & - & + & + & - & 4 \\
\hline Sperlich et al. 2013 & - & - & + & - & - & - & - & + & + & + & 4 \\
\hline
\end{tabular}

Note. 1 = Random allocation of the subjects; $2=$ Blind allocation; $3=$ Similar characteristics between groups at the baseline; 4 $=$ Blinding of researcher; $5=$ Blinding of the subjects; $6=$ Blinding of the researchers who administered the intervention; $7=$ Adequately follow-up; 8 = Intention to treat; 9 = results of between-group statistical comparisons are reported for at least one key outcome; 10 = Measures of variability for at least one key outcome.

Hamlin et al. (2012) and De Glanville \& Hamlin (2012) observed an improvement in the subsequent performance associated with the use of GCGs after an intense cycling bout. The mechanism behind this improvement is still unclear; however, it has been suggested that postexercise GCGs use stimulates venous blood flow (via the "muscle pump" system) by increasing systolic volume and cardiac output, which increases muscle arterial blood flow and subsequent recovery (Chatard et al., 2004; De Glanville \& Hamlin, 2012). Nevertheless, in the study conducted by Sperlichet et al. (2013) who used a similar intervention, but using GCGs in only one leg, the same benefits were not reported. This finding may be explained considering that a high thigh compression of $37 \mathrm{mmHg}$ was applied, which would affect muscle blood flow (creating a mechanical obstacle to circulation) not only on the surface but also in the deeper parts of muscle tissue. Studies have suggested that lighter compression - between 10 and $30 \mathrm{mmHg}$ - would be more efficient in recovery (Jakeman et al., 2010 b; Davies, Thompson \& Cooper, 2009).

In the study by Hamlin et al. (2012), a decrease in the time to perform a $3 \mathrm{~km}$ distance race in the group that used GCGs when compared to the placebo group was observed, indicating a possible improvement in the subsequent systolic volume to improve the venous return. The former result corroborated with a study that showed improvement in the venous flow in the vast lateral muscles as a result of the use of compression garments (Doan et al., 2003).
The efficacy of GCGs during an endurance race has already been the subject of four studies (Ali et al., 2010; Jakeman et al., 2010 b; Kraemer et al., 2010), in which GCGs were used in an attempt to attenuate markers of damage or improve performance. Two of them (Ali et al., 2007; Kraemer et al., 2010) corroborated with the results of the research from Hill et al. (2014), in which participants of a marathon were submitted to two different protocols of recovery. The authors concluded that the perceived muscle pain and the subjective perception of recovery were significantly lower in the group that used GCGs when compared to the control group (Hill et al., 2014).

The intervention performed by Kraemer et al. (2010) focused on strength exercises and the rate of fatigue, swelling and muscle soreness using GCGs to demonstrate that their use could improve muscle recovery within a period of 3 to 8 hours after exercise. The study used a protocol with resistance tests and presented positive results in consequence of the graduated clothes use, but did not report effects on inflammatory markers and muscle damage. This lack of effect may have occurred due to the rapid recovery of muscle tissue, as well as by the time of 48 hours elapsed until the measurement of the markers.

All articles included in this review presented different protocols and outcomes, as well as heterogeneous groups. The quality analysis of the studies performed using the PEDro scale showed low scores, ranging from 4 to 7 points, considering articles of low and medium qualities. Several studies did not present satisfactory 
methodological aspects, lacking the report of the blindness details of both participants and researchers, as well as information on confounding factors (included in the statistical analysis) and loss to follow-up. Given these facts, the results of the studies included in this review need to be carefully analyzed.

\section{CONCLUSION}

In conclusion, the positive effects of using GCGs on improving recovery and reduction of delayed muscle soreness after physical exercises are almost consensual in the existing literature. However, the methodological quality of the included studies requires careful consideration of the results. Studies with a more robust methodology seem to be necessary to allow more robust conclusions about the benefits of using GCGs in recovery and reduction of late pain after exercise.

\section{Acknowledgments:}

Nothing to declare.

\section{Conflict of interests:}

Nothing to declare.

\section{Funding:}

Nothing to declare.

\section{REFERENCES}

Ali, A., Caine, M. P. \& Snow, B. G. (2007). Graduated compression stockings: physiological and perceptual responses during and after exercise. Journal of Sports Sciences, 25(4), 413-419. doi: $10.1080 / 02640410600718376$.

Ali, A., Creasy, R. H. \& Edge, J. A. (2010). Physiological effects of wearing graduated compression stockings during running. European Journal of Applied Physiology, 109(6), 1017-1025. doi: 10.1007/s00421-010-1447-1.

Berry, M .J. \& McMurray, R. G. (1987). Effects of graduated compression stockings on blood lactate following an exhaustive bout of exercise. American Journal of Physical Medicine \& Rehabilitation, 66(3), 121-132.

Doan, B. K., Kwon, Y.W., Newton, R. U., Shim, J., Popper, E. M., Rogers, R. A., ... \& Kraemer, W. J. (2003). Evaluation of a lower-body compression garment. Journal of Sports Sciences, 21 (8), 601-610. doi: 10.1080/0264041031000101971.

Bringard, A., Perrey, S. \& Belluye, N. (2006). Aerobic energy cost and sensation responses during submaximal running exercise -- positive effects of wearing compression tights. International Journal of Sports Medicine, 27(5), 373-378.

Chan, V., Duffield, R. \& Watsford, M. (2016). The effects of compression garments on performance of prolonged manual-labour exercise and recovery. Applied Physiology, Nutrition, and Metabolism, 41(2), 125-132. doi: 10.1139/apnm2015-0335.

Chatard, J. C., Atlaoui, D., Farjanel, J., Louisy, F., Rastel, D. \& Guezennec, C. Y. (2004). Elastic stockings, performance and leg pain recovery in 63-year-old sportsmen. European Journal of Applied Physiology, 93(3), 347-352. doi: 10.1007/s00421004-1163-9.

Davies, V., Thompson, K. G. \& Cooper, S. M. (2009). The effects of compression garments on recovery. The Journal of Strength \& Conditioning Research, 23(6), 1786-1794. doi: 10.1519/JSC.0b013e3181b42589.

De Glanville, K. M. \& Hamlin, M. J. (2012). Positive effect of lower body compression garments on subsequent 40-kM cycling time trial performance. The Journal of Strength \& Conditioning Research, 26(2), 480-486. doi: 10.1519/JSC.0b013e318225ff61.

Driller, M. \& Halson, S. L. (2013). The effects of wearing lower body compression garments during a cycling performance test. International Journal of Sports Physiology and Performance, 8(3), 300-306.

Duffield, R. \& Portus, M. (2007). Comparison of three types of full-body compression garments on throwing and repeat-sprint performance in cricket players. British Journal of Sports Medicine, 41 (7), 409-414. doi: 10.1136/bjsm.2006.033753.

Duffield, R., Edge, J., Merrells, R., Hawke, E., Barnes, M., Simcock, D. \& Gill, N. (2008). The effects of compression garments on intermittent exercise performance and recovery on consecutive days. International Journal of Sports Physiology and Performance, 3(4), 454-468.

Fernandes, S., Rodrigues, E. \& Vianna, D. L. (2011). Efeito da hidroterapia no edema de membros inferiores. Revista Mackenzie de Educação Física e Esporte, 10(1), 89-97.

Figueiredo, M. A., Filho, A. D. \& Cabral, A. L. (2004). The effects of elastic stockings on the venous hemodynamic of patients with chronic venous insufficiency. Jornal Vascular Brasileiro, 3(3), 231237.

França, L. H. G. \& Tavares, V. (2003). Chronic venous insufficiency. An update Jornal Vascular Brasileiro, 2(4), 318-328.

Gill, N. D., Beaven, C. M. \& Cook, C. (2006). Effectiveness of post-match recovery strategies in rugby players. British Journal of Sports Medicine, 40(3), 260-263. doi: 10.1136/bjsm.2005.022483.

Goto, K. \& Morishima, T. (2014). Compression garment promotes muscular strength recovery after resistance exercise. Medicine and Science in 
Sports and Exercise, 46(12), 2265-2270. doi: 10.1249/MSS.0000000000000359.

Hamlin, M. J., Mitchell, C. J., Ward, F. D., Draper, N., Shearman, J. \& Kimber, N. (2012). Effect of compression garments on short-term recovery of repeated sprint and 3-km running performance in rugby union players. The Journal of Strength and Conditioning Research, 26(11), 2975-2982. doi: 10.1519/JSC.0b013e3182711e0b.

Hill, J., Howatson, G., van Someren, K., Gaze, D., Legg, H., Lineham, J. \& Pedlar, C. (2017). The Effects of Compression Garment Pressure on Recovery from Strenuous Exercise. International Journal of Sports Physiology and Performance, 4, 1-22. doi: 10.1123/ijspp.2016-0380.

Hill, J., Howatson, G., van Someren, K., Walshe, I. \& Pedlar, C. (2014). The influence of compression garments on recovery following marathon running. The Journal of Strength and Conditioning Research, 28(8), 2228-2235. doi: 10.1519/JSC.0000000000000469.

Jakeman, J. R., Byrne, C. \& Eston, R. G. (2010). Efficacy of lower limb compression and combined treatment of manual massage and lower limb compression on symptoms of exercise induced muscle damage in women. The Journal of Strength and Conditioning Research, 24(11), 3157-3165. doi: 10.1519/JSC.0b013e3181e4f80c.

Jakeman, J. R., Byrne, C. \& Eston, R. G. (2010) B. Lower limb compression garment improves recovery from exercise-induced muscle damage in young, active females. European Journal of Applied Physiology, 109(6), 1137-1144. doi: 10.1007/s00421-010-1464-0.

Kelechi, T. J., Johnson, J. J. \& WOCN Society. (2012). Guideline for management of wounds in patients with lower-extremity venous disease. Journal of Wound Ostomy \& Continence Nursing, 39(6), 598606. doi: 10.1097/WON.0b013e31827179e9.

Kemmler, W., von Stengel, S., Köckritz, C., Mayhew, J., Wassermann, A. \& Zapf J. (2009). Effect of Compression Stockings on Running Performance in Men Runners. The Journal of Strength $\mathcal{E}$ Conditioning Research, 23(1), 101-105. doi: 10.1519/JSC.0b013e31818eaef3.

Kraemer, W. J., Bush, J. A., Bauer, J. A., McBride, T. T., Paxton, N. J., Clemson, A., ... \& Newton, R. U. (1996). Influence of compression garments on vertical jump performance in NCAA division I volleyball players. The Journal of Strength $\mathcal{E}$ Conditioning Research, 10(3), 180-183. doi: 10.1519/00124278-199608000-00009.

Kraemer, W. J., Bush, J. A., Newton, R. U., Duncan, N. D., Volek, J. S., Denegar, C. R., ... \& Sebastianelli, W. J. (1998). Influence of a compression garment on repetitive power output production before and after different types of muscle fatigue. Sports Medicine Training \& Rehabilitation, 8(2), 163-184. doi: 10.1080/15438629809512525.
Kraemer, W. J., Bush, J. A., Wickham, R. B., Denegar, C. R., Gómez, A. L., Gotshalk, L. A., ... \& Sebastianelli, W. J. (2001). Continuous compression as an effective therapeutic intervention in treating eccentric-exerciseinduced muscle soreness. Journal of Sport Rehabilitation, 10(1), 11-23. doi: 10.1123/jsr.10.1.11.

Kraemer, W. J., Flanagan, S. D., Comstock, B. A., Fragala, M. S., Earp, J. E., Dunn-Lewis, C., ... \& Maresh, C. M. (2010). Effects of a whole body compression garment on markers of recovery after a heavy resistance workout in men and women. The Journal of Strength \& Conditioning Research, 24(3), 804-814. doi: 10.1519/JSC.0b013e3181d33025.

Liberati, A., Altman, D. G., Tetzlaff, J., Mulrow, C., Gøtzsche, P. C., Ioannidis, J. P. A., ... Moher, D. (2009). The PRISMA Statement for Reporting Systematic Reviews and Meta-Analyses of Studies That Evaluate Health Care Interventions: Explanation and Elaboration. PLOS Medicine, 6(7), e1000100.

https://doi.org/10.1371/journal.pmed.1000100

Miyamoto, N. \& Kawakami, Y. (2012). No graduated pressure profile in compression stockings still reduces muscle fatigue. International Journal of Sports Medicine, 36(3), 220-225. doi: 10.1055/s0034-1390495.

Nelson, E. A. \& Bell-Syer, S. E. M. (2012). Compression for preventing recurrence of venous ulcers. The Cochrane Database of Systematic Reviews, 15(8). doi: 10.1002/14651858.CD002303.

Partsch, H., Flour, M. \& Smith, P. C. (2008). International Compression Club. Indications for compression therapy in venous and lymphatic disease consensus based on experimental data and scientific evidence. International Angiology, 27 (3), 193-219.

Shiwa, S. R., Costa, L. O. P, Costa, L. C. M., Moseley, A., Junior, L. C. H., Venâncio, R., ... \& Lopes, A. D. (2011). Reproducibility of the Portuguese version of the PEDro Scale. Cadernos de Saúde Pública, 27(10), 2063-2067. doi: 10.1590/S0102311X2011001000019.

Simao, R., Farinatti, T., Polito, M. D., Maior, A. S. \& Fleck, S. J. (2007). Influence of exercise order on the number of repetitions performed and perceived exertion during resistance exercises. The Journal of Strength \& Conditioning Research, 21 (1), 23-28. doi: 10.1519/R-18765.1.

Sperlich, B., Born, D. P., Kaskinoro, K., Kalliokoski, K. K. \& Laaksonen, M. S. (2013). Squeezing the muscle: compression clothing and muscle metabolism during recovery from high intensity exercise. PLoS One. 8(4), e60923. doi: 10.1371/journal.pone.0060923. 